\title{
Novel Non-Cerevisiae Saccharomyces Yeast Species Used in Beer and Alcoholic Beverage Fermentations
}

\author{
James Bruner * and Glen Fox* \\ Food Science and Technology, University of California, Davis, CA 95616, USA \\ * Correspondence: jrbruner@ucdavis.edu (J.B.); gpfox@ucdavis.edu (G.F.)
}

Received: 28 October 2020; Accepted: 22 November 2020; Published: 24 November 2020

\begin{abstract}
A great deal of research in the alcoholic beverage industry was done on non-Saccharomyces yeast strains in recent years. The increase in research interest could be attributed to the changing of consumer tastes and the search for new beer sensory experiences, as well as the rise in popularity of mixed-fermentation beers. The search for unique flavors and aromas, such as the higher alcohols and esters, polyfunctional thiols, lactones and furanones, and terpenoids that produce fruity and floral notes led to the use of non-cerevisiae Saccharomyces species in the fermentation process. Additionally, a desire to invoke new technologies and techniques for making alcoholic beverages also led to the use of new and novel yeast species. Among them, one of the most widely used non-cerevisiae strains is S. pastorianus, which was used in the production of lager beer for centuries. The goal of this review is to focus on some of the more distinct species, such as those species of Saccharomyces sensu stricto yeasts: S. kudriavzevii, S. paradoxus, S. mikatae, S. uvarum, and S. bayanus. In addition, this review discusses other Saccharomyces spp. that were used in alcoholic fermentation. Most importantly, the factors professional brewers might consider when selecting a strain of yeast for fermentation, are reviewed herein. The factors include the metabolism and fermentation potential of carbon sources, attenuation, flavor profile of fermented beverage, flocculation, optimal temperature range of fermentation, and commercial availability of each species. While there is a great deal of research regarding the use of some of these species on a laboratory scale wine fermentation, much work remains for their commercial use and efficacy for the production of beer.
\end{abstract}

Keywords: yeast; Saccharomyces; fermentation; alcohol; beer; wine

\section{Introduction}

Fermented beverages have played an important and special role over the course of human history due to their economic and cultural importance, perhaps even lending to the beginning of modern civilizations [1,2]. Archaeological evidence places the oldest fermented beverage in the fertile crescent, as far back as 11,000 BCE [3,4], and based on the agricultural evidence of the time and region, that beverage was likely beer. While beer originally could have been an accidental beverage, it progressed into one of the most artfully crafted beverages known to man. No longer thought of as just an art, the science of beer led to several very important landmarks in scientific history (Table 1). As scientific discoveries keep developing, there are some amazing innovations that led to advances in the quality and stability of beer, over the past 40 years [5]. However, minimal advancement was made when considering the raw ingredients used in the brewing process. 
Table 1. Significant landmarks of the 150 years from 1760-1910 that came from scientists working at breweries or specifically studying beer and its adjacent ingredients.

\begin{tabular}{cccc}
\hline Year & Scientist & Employment & Discovery \\
\hline 1762 & Michael Combrune & $\begin{array}{c}\text { Brewer's Company } \\
\text { Middlesex }\end{array}$ & using a thermometer for analysis [2] \\
\hline 1769 & James Baverstock & family brewery & using a hydrometer for analysis [2] \\
\hline 1833 & $\begin{array}{c}\text { Anselme Payen and } \\
\text { Jean-François Perzoz }\end{array}$ & École Centrale Paris & $\begin{array}{c}\text { discovered diastase enzyme and cellulose while } \\
\text { working with barley [2] }\end{array}$ \\
\hline 1843 & Karl J.N. Balling & Polytechnic in Prague & invents the balling saccharimeter [6] \\
\hline 1843 & $\begin{array}{c}\text { James Joule and } \\
\text { Lord Kelvin }\end{array}$ & family brewery & create temperature scale and first law of \\
thermodynamics [7]
\end{tabular}

On a base level, beer consists of four main ingredients-malt, water, hops, and yeast, and the brewing process could be separated into a hot side and a cold side. In the most basic overview of the brewing process, the hot side begins when malted cereal grains are crushed and combined with warm water so the maltose sugar is hydrolyzed from starch, the liquid is then boiled with hops to add bitterness and flavor; this liquid, called wort, provides the nutrients for yeast. Moving from the hot side to the cold side, wort is subsequently chilled for fermentation (Figure 1a); yeast is added, metabolizing 50 to 80 percent of the sugar and nutrients to fermentation products, leaving behind non metabolized proteins, oligosaccharides, and other compounds [12-14]. The resultant sugar profile of brews can vary, based on the malting and mashing conditions, but typical mashes might contain $60.0 \%$ maltose, $20.0 \%$ glucose, $10.0 \%$ maltotriose, and $5.0 \%$ of both sucrose and fructose [15].

Conversely, wine has just two main ingredients, grapes and yeast, and tends to have a much simpler process flow than beer (Figure 1b). Grapes are picked and sorted from the vineyard before being crushed, to release the sugary juice from the interior, for the varying fermentation profiles of red or white wine. When producing white wine the skins and pomace are pressed and filtered from the juice before the addition of yeast for fermentation. While red wine is fermented on the pomace to get the color from the polyphenols within the skins and seeds, before being pressed and filtered for aging. Wine might also have an additional malolactic fermentation to soften the malic acid into lactic acid, but the lactic acid bacteria can produce a buttery diacetyl flavor that is only desirable in certain styles [16]. In wine, the resultant sugar profile can vary, based on that of the grapes used, but the majority $(\sim 95.0 \%)$ of sugars are already present in monosaccharide form, as equal parts glucose and fructose, which the yeast can ferment without the assistance of enzymes [17,18].

For most of the scientific history of beer, Saccharomyces cerevisiae was the yeast used to produce alcohol [19-21] although the first pure culture isolate of brewing yeast was $S$. carlsbergensis (later renamed S. pastorianus) [22]. For alcoholic fermentation, the general rule of thumb for the amount of yeast to use, known as the pitching rate, is one million cells per milliliter per percent of sugar in solution $[9,12,23]$. S. cerevisiae, when used at the proper pitching rate, takes the maltose and other sugars produced from the hot side of the brewing process [15], and anaerobically converts the disaccharides into carbon dioxide $\left(\mathrm{CO}_{2}\right)$ and ethanol. More than 600 flavor active compounds can also be produced during the alcoholic fermentation process, depending on type of beverage produced (Figure 2) [24-26]. Yeast works via an anaerobic pathway of glycolysis; if oxygen is present it performs respiration and cell reproduction [27]. 
(a)

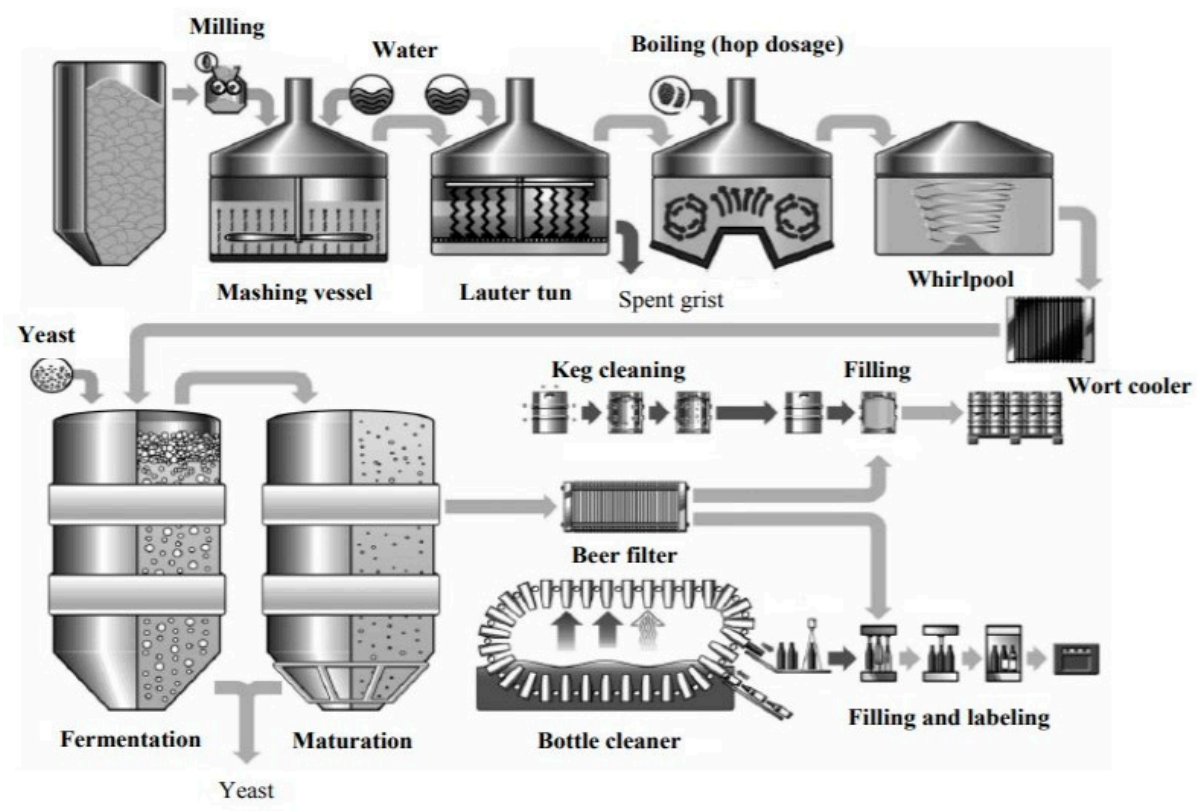

(b)
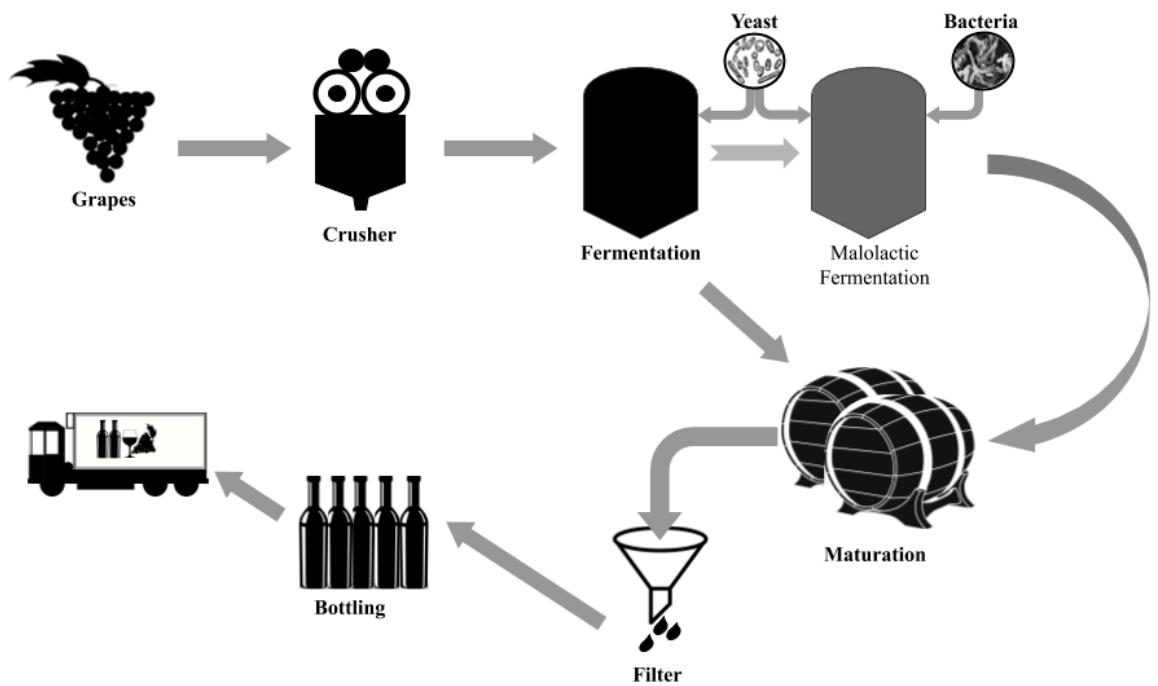

Figure 1. (a) Schematic diagram of the brewing process, as presented in Magalhães et al. 2009 [14]. (b). Schematic diagram of the winemaking process as outlined and described by Water house et al. 2016 [16].

In Stage 1 of alcoholic fermentation, free glucose is assimilated first, followed by the hydrolyzation of maltose or other disaccharides into two glucose, by the enzyme alpha glucosidase (a.k.a maltase, EC 3.2.1.20). Several other enzymatic destabilization and phosphorylation reactions then happen in Stage 1, which turns the substrate into glyceraldehyde-3-phosphate (G3P) and dihydroxyacetone phosphate (DHAP). Stage 2 oxidizes G3P and DHAP, as well as the ADP generated previously, to create ATP as energy for the cell and pyruvate. Stage 3 enzymatically decarboxylates pyruvate to acetaldehyde and $\mathrm{CO}_{2}$ that leaves the cell, before the alcohol dehydrogenase converts the acetaldehyde to ethanol in Stage 4 (Figure 2). In brewing, yeast is typically reused (repitched) for ten generations or more [9], while in wine, the yeast is generally used far lesser times, due to the prominence of other microorganisms and the higher mortality from more stressful conditions of osmotic pressure and higher ethanol concentrations [28]. In most cases, serial repitching can cause genetic mutation within the cells and the desired flavor profile might no longer be attainable [29-32]. 


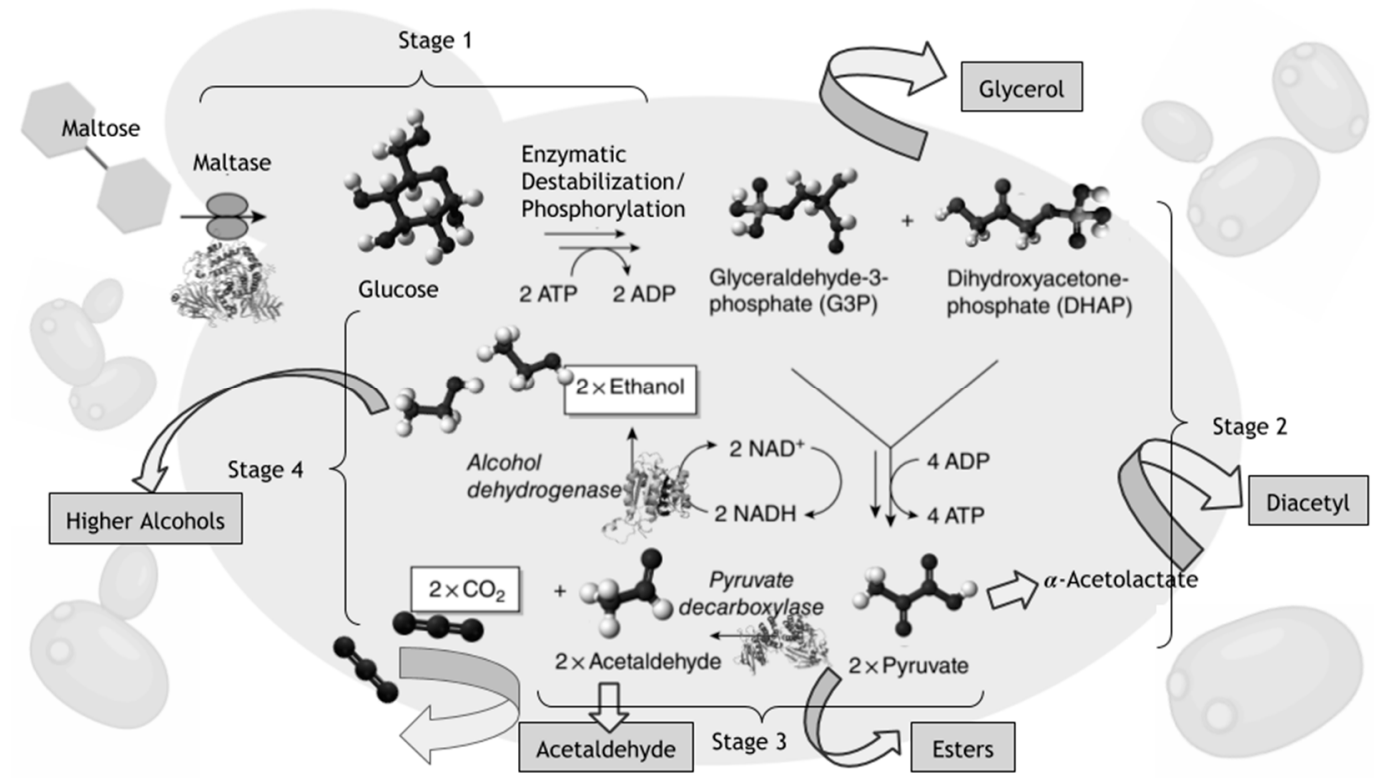

Figure 2. The metabolic role of Saccharomyces yeast in the development of flavor for fermented alcoholic beverages. The sole products of yeast fermentation are not just ethanol and $\mathrm{CO}_{2}$, this schematic representation shows the derivation and synthesis of flavor active compounds from sugar, amino acids, and sulfur metabolism, delineated by the arrows on the diagram. Alcoholic fermentation of beer by Saccharomyces is the substrate level phosphorylation anaerobic pathway of glycolysis, which converts maltose sugar into ethanol and carbon dioxide.

Interest in brewing beer with novel yeast strains and applying Saccharomyces cerevisiae in new methods outside of traditional beer fermentation [33,34] has increased in recent years, due to the growing consumer tastes of sour and wild mixed-fermentation beers, as well as using some of these novel species for low or no alcohol beer production [35,36]. A great deal of research in the brewing industry was done on non-Saccharomyces yeast strains, such as Brettanomyces, Pichia, Hanseniaspora, Metschnikowia, and Torulaspora [37-39]. Furthermore, the search for unique flavors and aromas, and a desire to invoke new technologies and techniques for making alcoholic beverages led to the use of non-cerevisiae Saccharomyces spp. in the alcoholic fermentation process [40,41].

While the most widely used non-cerevisiae species is S. pastorianus, traditionally used in the production of lager beer around the world [42-44], this review focuses on some of the more distinct species. The focus is on five species of Saccharomyces sensu stricto (Sss) yeasts, S. kudriavzevii, S. paradoxus, S. mikatae, S. uvarum, and S. bayanus, as well as other novel species not currently in the Sss, such as S. abulensis and S. florentinus. When selecting yeast strains for fermentation, brewers consider its attenuation (the amount of sugar consumed by the yeast), flocculation (the yeast's ability to clump together and fall out of solution), fermentation temperature range, effects on flavor profile, capacity for reuse, and supply chain availability [45]. These facets, as well as a yeast's ability to ferment various carbon sources, morphological characteristics, and genetic hybridization can all assist brewers, when adopting a new strain.

\section{Saccharomyces Species Diversity}

Since Louis Pasteur's groundbreaking and historic report that fermentation was caused by a microorganism instead of a spontaneous mystery [8], the Saccharomyces genome was continuously studied, with several distinct species identified [46]. This diversity was termed the Saccharomyces sensu stricto (Sss) complex and is currently composed of ten genetically distinct species, all of which are capable of metabolizing glucose to produce ethanol (Figure 3). Each of these species was perceptibly delineated from other Saccharomyces species, through studies of reproductive isolation and application of the biological species concept [31,47-49]. All Sss species were isolated from unique sources in nature, 
including tree bark, flowers, fruit, and insects, demonstrating their lineage from wild type to the cultured stock of Saccharomyces spp. While all members of the Sss were proven to produce energy with fermentation, and many of these species are novel, some were used and studied for their potential use in commercial alcohol production for human consumption. The distribution of S. cerevisiae and S. pastorianus were long linked to alcoholic beverage production, along with minor mentions of other species in the Sss complex. Cultured species, specific to beer production, were shown to have evolved from European wine and Asian sake fermentations [21,50], therefore, its relation to wine production proliferates much of the research.

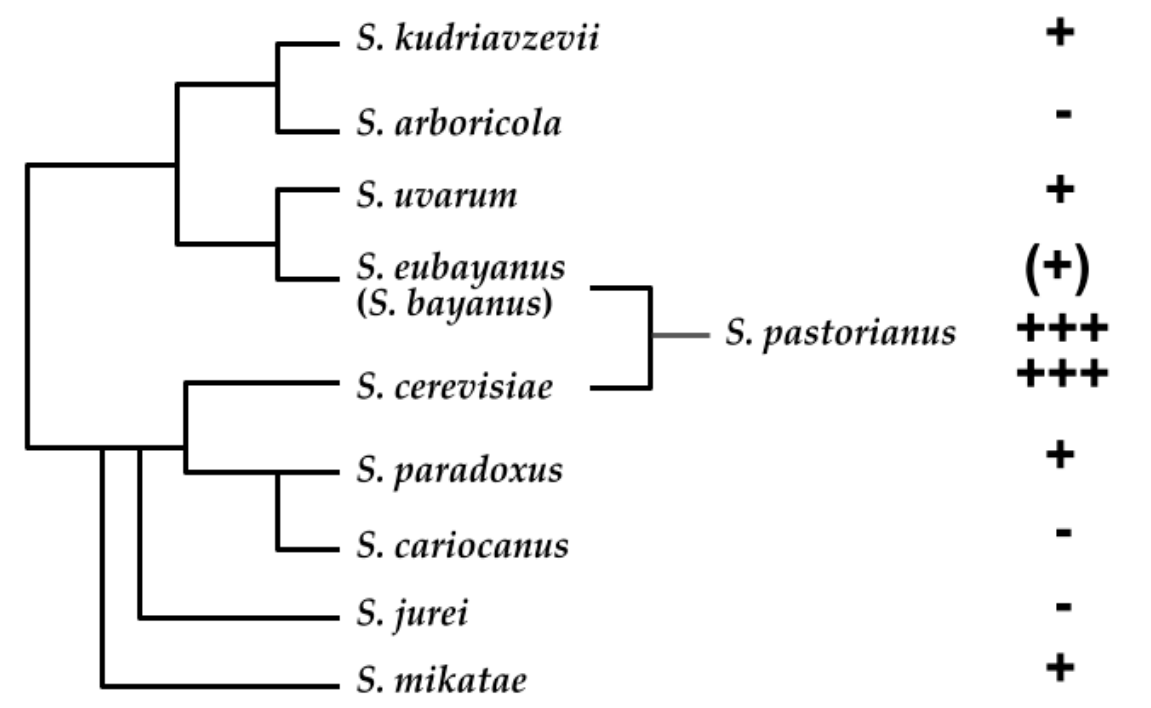

Figure 3. Saccharomyces species phylogeny shown; all were effectively isolated from natural sources (i.e., trees, fruit, insects). Saccharomyces bayanus is listed in parenthesis to indicate it was derived from multiple hybridization events. S. pastorianus is shown as a genetic hybrid of S. eubayanus and S. cerevisiae. Usage indicated with plus signs (+) for current use in industry, with S. cerevisiae and S. pastorianus showing the most profound use in the current alcoholic fermentation industry, and negative signs (-) for no known use. S. cariocanus is known to be harboring just four translocated chromosomes different than S. paradoxus. Figure adapted from Fay 2012 [51].

\section{Saccharomyces kudriavzevii}

S. kudriavzevii was first isolated from a decaying leaf and has since been isolated repeatedly from the bark of oak trees in Portugal and France [52,53]. The yeast is a multipolar budding species, with a size of $5-10 \mu \mathrm{m}$, and an oval to slightly elongated shape [47]. It was shown to ferment glucose, sucrose, and maltose, but it did not ferment lactose, melibiose, or starch, which are common characteristics of Sss yeast (Table 2). S. kudriavzevii is a naturally occurring S. cerevisiae hybrid that might constitute $23-100 \%$ of the genome for some yeast [54,55], including Belgian trappist ale strains, such as Chimay, Westmalle, and Orval, and wass also genetically isolated in draft beer from the United Kingdom, Germany, and New Zealand [56]. This implies that the attenuation, flocculation, and flavor profiles of S. kudriavzevii might be similar to that of most Belgian strains. This meant low flocculation, high attenuation, and phenolic off-flavor positive (POF+) [45,57], though there is research in the wine industry that suggests $S$. kudriavzevii ferments slowly and produces less ethanol when used on grape juice [58]. Other research suggests it has high flocculation, as in overnight liquid culture, it grew into spherical 2-3 mm pellets [31]. 
Table 2. Physiological characteristics that distinguish each species of the Saccharomyces sensu stricto complex are discussed. Growth ability scored as positive (+), negative (-), evidence of both positive and negative $(-,+)$, and unknown $(\mathrm{u})$. Ethanol tolerance is defined as being able to grow in the presence of $2.5 \% v / v \mathrm{EtOH}$, the low-end strength of standard beer. Attenuation and flocculation scored on a relative basis scale, ranging from low, to moderate, to high. Type strain as defined in MycoBank (mycobank.org), origin, isolation, and commercial availability, as defined in the cited literature.

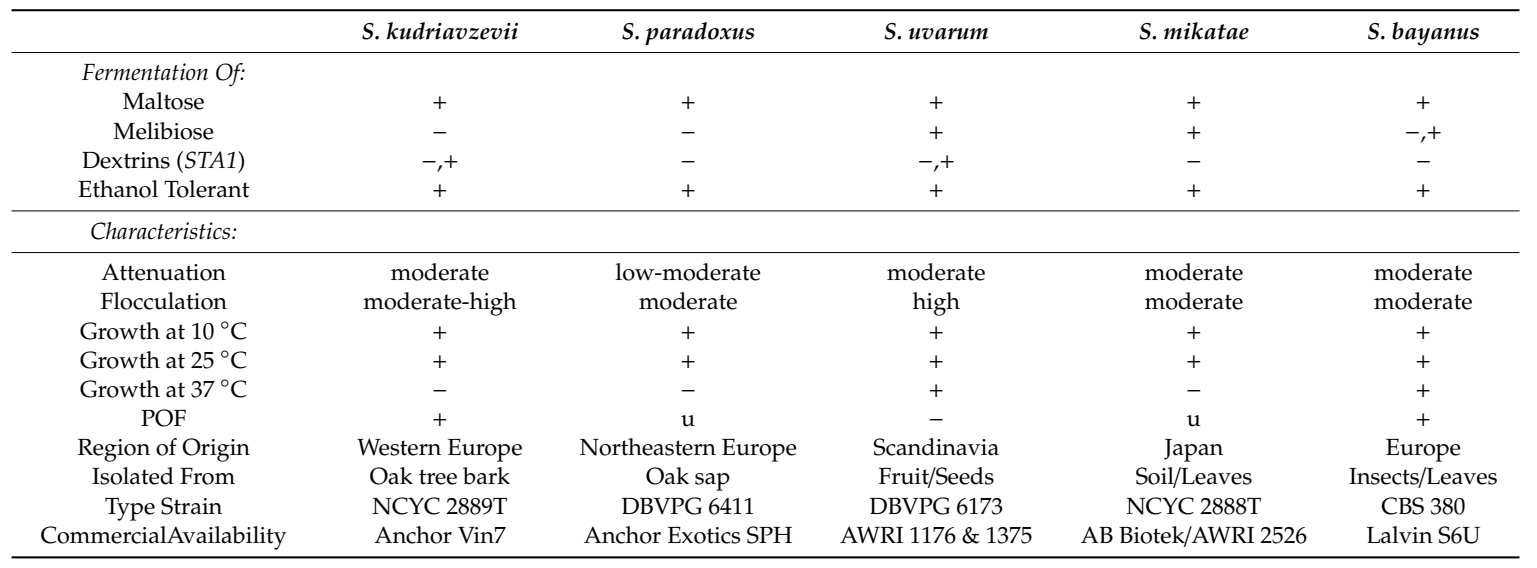

It is advised to ferment S. kudriavzevii in tandem with a traditional Saccharomyces [59] and it was shown to form a triple hybrid complex with $S$. cerevisiae and $S$. uvarum, as it was isolated as such from farmhouse ciders made in France [60,61]. S. kudriavzevii is a cryophilic strain in the Sss that prefers fermentation temperatures in the $10-15^{\circ} \mathrm{C}$ range $[52,62,63]$, and is currently used to ferment lower temperature pinot noir and lager beer in Europe [54]. The only current commercially available example is Anchor Oenology's Vin7 strain, developed in Stellenbosch, South Africa, for enhancing thiol aromas in white wine [64,65], but it stands to reason that it can be isolated from previously noted commercial beer examples. Due to its cryophilic tendencies and aromatic potential, S. kudriavzevii has potential for use in the production of hoppy lager beers in the brewing industry. Further research remains to be done on this species, considering it is $\mathrm{POF}+$ and it is likely also diastaticus (STA1) positive, meaning it could ferment residual maltodextrins. Additionally, minimal commercial production was done with the direct intention of using $S$. kudriavzevii, as most fermentations did not take place with the intention of the use of this species.

\section{Saccharomyces paradoxus}

S. paradoxus is one of the first isolates of the Sss [66], a wild-type strain commonly isolated from the bark of deciduous trees and occasionally from fruit and insects in North America and Eastern Europe [67-69]. Even though genetically S. cerevisiae and S. paradoxus were proven to be distinct species [70], phylogenetically the two were the closest relatives in the Sss (Figure 3) and were 90\% genetically similar [55]. They share the same morphological and phenotypic characteristics, such as being spherical or ellipsoid in shape, with a diameter of 1-5 $\mathrm{m}$ [71]. Previous research indicates mixed results of the fermentative capacity of $S$. paradoxus, but it has the ability to convert glucose into ethanol and a relatively high alcohol tolerance [47,72,73]. It is a positive fermenter for glucose, sucrose, and maltose, but it does not ferment lactose, melibiose, or starch (Table 2). Little evidence exists for the domestication and commercial use of $S$. paradoxus in alcohol fermentation, but it was found to be naturally co-fermenting with S. cerevisiae in Eastern European wine fermentations [73,74], as well as with S. cerevisiae, S. bayanus, S. cariocanus, S. kudriavzevii, S. mikatae, and S. pastorianus in indigenous African sorghum beer [75].

In laboratory fermentations, the optimal growth temperature for S. paradoxus falls $7^{\circ} \mathrm{C}$ lower than $S$. cerevisiae, and is likely cryophilic, due to the climates in which it is found, but S. paradoxus is yet to be trialed extensively in a production environment [76,77]. Unfortunately, no information 
exists on the attenuation or flocculation characteristics of S. paradoxus, nor are there any commercially produced examples of the purely isolated species, but it does seem to have positive sensory attributes in white wine fermentations $[73,74]$. There is a commercially available hybrid of S. paradoxus and S. cerevisiae produced by Anchor Oenology, which when used for Syrah and Merlot wine fermentations, shows increased aromas of cherries, strawberries, cocoa, and floral notes, and the wine is described as full-bodied, well-balanced, complex and intense [78]. Much work remains to be done on the versatility of this species for the brewing industry, but it might have potential for unique and novel flavor characteristics if a pure culture from a genetic bank is obtained for further experimentation.

\section{Saccharomyces mikatae}

S. mikatae is a natural genetic hybrid that results from introgression events with $S$. cerevisiae and S. paradoxus [55,79], and its current hybrids are described for use in industrial wine fermentation. This hybrid was deliberate, created in a lab with the intent of creating greater complexity in resultant wines, akin to those that are spontaneously fermented, but more easily controlled due to the inclusion of typical S. cerevisiae yeast $[80,81]$ S. mikatae was first isolated from decaying leaves and soil in Japan $[47,60]$. It is ovoid in shape and approximately 5-9 $\mu \mathrm{m}$ in diameter; it reproduces by multipolar budding, and generally appears in pairs or short chains. S. mikatae was also shown to form a pellicle after 25 days at $20^{\circ} \mathrm{C}$, similar to Brettanomyces and other wild-type yeasts [47]. The inclusion of S. mikatae in the Sss means it is capable of alcoholic fermentation and assimilation of glucose, it is also capable of fermenting maltose, sucrose, and melibiose, but not lactose or starch (Table 2). However, S. mikatae might have a lower attenuation, due to genetic diversion from $S$. cerevisiae, while still exhibiting similar levels of flocculence [31].

S. mikatae readily creates hybrids with $S$. cerevisiae, and these hybrids were shown to produce higher concentrations of multiple compounds that yield fruity, banana, floral, and sweet perfume aromas in the fermentation of white wine [80,81]. Although no information on beer fermentation with either the type strain or any hybrids exist, the additional amounts of certain volatile compounds in the research by Bellon et al. $(2013,2019)$ might show signs of this yeast's production of phenolic off flavors. S. mikatae grows readily in temperatures from $4-30^{\circ} \mathrm{C}$, with expected slower growth in the range limits and no growth outside the range, making it a cryotolerant fermenter $[47,63]$. Commercial availability is limited, but yeast manufacturer AB Biotek commenced exploratory production of an S. mikatae and S. cerevisiae hybrid, AWRI 2526; brewers and winemakers can expect the hybrid as an active dried yeast product that is expected to be available for trials, by the fall of 2020 [81].

\section{Saccharomyces uvarum}

S. uvarum is a fairly well-known member of the $S s s$, originally believed to be identical to S. bayanus and often referred to as S. bayanus var. uvarum, it was shown to be a genetically distinct Saccharomyces species [82-84]. S. uvarum is also similar in size and shape to S. bayanus, being spherical or ellipsoid in shape, with a diameter of 1-5 $\mu \mathrm{m}$, and reproducing by multipolar budding. S. uvarum was isolated in natural European wine and cider fermentations [85-87], as well as in South American chicha fermentations [88,89], but was first isolated in 1894 and described in 1898 by M.W. Beijerinck, from spontaneous wine fermentation [90]. S. uvarum is known to hybridize with S. cerevisiae, S. bayanus, and S. pastorianus [85,91,92], and thus can show signs of being POF+ and possibly might have the STA1 gene for diastaticus [91,93]. S. uvarum showed the capacity to ferment glucose, sucrose, melibiose, and maltose, but it does not ferment lactose. S. uvarum is a known bottom-fermenting yeast, meaning it acts similar to a $S$. bayanus or $S$. pastorianus when not in hybrid form, offering cryotolerance [94], moderate attenuation, and high flocculation (Table 2).

Research with wine showed that $S$. uvarum produces comparatively higher amounts of volatile aromatics when fermented cold [95], implying potential use as a lager strain. In Chardonnay winemaking trials, wines were described as showing apricot, cooked orange peel, citrus, lime, honey, and nutty aromas with some tasters, and estery, pineapple, peach, melon, and floral 
aromas with others $[80,96]$. While $S$. uvarum continues to predominate in spontaneous European wine fermentations [86,87,97] and is a known species in some Norwegian kveik hybrid strains [91], its commercial availability is limited to the Australian Wine Research Institute at this time [98]. Cryotolerance and increased aromatic potential means $S$. uvarum could be used in the production of some complex and eccentric lagers in the brewing industry, but currently, it has only been isolated as part of a hybrid culture in the aforementioned kveik beer. Further research remains to be done on the brewing potential of $S$. uvarum, but brewers should be aware of the increased aromatic character that might come from the POF+ genes.

\section{Saccharomyces bayanus}

S. bayanus is a well-studied species in the SsS and is often used as a model organism for comparative functional genomics studies of yeast, based on introgression and interspecific hybridization [99]. It is genetically similar to $S$. cerevisiae, but evolved to be a distinct member of the Saccharomyces sensu stricto complex [55,100], and is now referred to as $S$. bayanus var. bayanus, in order to delineate it from S. eubayanus and S. uvarum $[43,101]$. S. bayanus was previously thought to be the parent of the lager strain, S. pastorianus $[43,60,85]$, but the hybridization event that produced lager brewing yeast is now proven to have occurred between $S$. cerevisiae and S. eubayanus $[21,50,102,103]$. While S. bayanus might not be the true hybrid parent of the most used brewing yeast in the world, it still forms natural hybrids with other members of the Sss and was identified in these complexes in the fermentation of wine [62,85,104]. While it was first isolated from turbid beer in 1927 [105], S. bayanus was also isolated from beer, wine, fruit, and even soda [47]. S. bayanus is ellipsoid to elongate in shape, with a diameter of 1-5 $\mu \mathrm{m}$, and reproduces by multipolar budding. Research showed it to be a positive fermenter for glucose, sucrose, and maltose. Other studies reported $S$. bayanus to show both positive and negative fermentation of melibiose, but it does not ferment lactose or starch (Table 2).

S. bayanus is well-known as a fermenter of beer and cider $[43,105,106]$, but is most commonly used in wine $[96,103,107]$. It can be purchased from several commercial suppliers, but unfortunately several commercially available strains were genetically identified as S. cerevisiae, including the famous Lalvin EC-1118 strain that was originally typed S. bayanus [108,109]. S. bayanus ferments best in the upper end of the lager strain temperature range of 10 to $21^{\circ} \mathrm{C}[77,101]$, is moderately flocculant [31], and has a fairly standard attenuation [110], as expected, given its genetic similarity to $S$. pastorianus lager yeast. The commercially available hybrid of S. bayanus and S. cerevisiae available from Lallemand, Lalvin S6U, is known to increase the varietal characteristics in white wine, and might produce elevated levels of POF [111,112]. More research needs to be carried out with regards to the flavor profile of beers made with $S$. bayanus, but the research on wine and its history as a potential lager strain means, it is capable of fermenting remarkable lager style beers.

\section{Other Saccharomyces spp. Used in Alcoholic Fermentation}

Several other novel species of Saccharomyces used in alcoholic fermentation were determined to be genetically distinct by current research but might not yet be included in the Saccharomyces sensu stricto complex. S. abulensis is a novel species dubbed the "Santa Maria strain" and was isolated from yeast originating from breweries in Madrid and Sevilla, Spain [92]. S. florentinus, formerly known as S. pyriformis, is a species of yeast isolated from the scoby of traditionally fermented ginger beer, known as "bees wine," but is yet to be used in commercial production of beer [113,114]. Three other strains included in the phylogenetic tree of the Sss (Figure 3) exist-S. arboricola, S. jurei, and S. cariocanus-but research is limited on their fermentation capacity. S. arboricola is a wild-type hybrid of S. bayanus and S. kudriavzevii, which was isolated from oak and beechwood bark in China $[115,116]$, and is currently being used in sake production [117]. S. jurei is closely related to S. mikatae and S. paradoxus and was isolated from a high altitude tree bark in France; little is known of its fermentative capacity [118]. S. cariocanus, isolated from insects in South America [119], is a wild-type hybrid of S. paradoxus, which is capable of fermenting sucrose and shows ethanol tolerance [120]. 
These yeasts are not members of the $S s s$, but is likely to be included, as the complex underwent many changes over the years, in accordance with the system employed in classifying yeast cultures. Very little information exists on these yeasts' ability to ferment beer or their use in a commercial setting, but by contacting genetic banks and yeast culture collections directly, the strain type could be obtained for further experimentation. There also exists multiple variants of S. cerevisiae, such as var. boulardii, which is known to produce higher levels of polyphenols, and can thus be used in functional probiotic beer [121-126]. Another variant, var. diastaticus, can cause over-attenuation [127-129], which was discussed earlier as having the STA1 gene.

\section{Conclusions}

The non-cerevisiae Saccharomyces species discussed in this review, have the ability to ferment glucose and maltose into ethanol, anaerobically. Most are members of the Saccharomyces sensu stricto complex, while some are yet to be defined within the species complex classification. S. kudriavzevii is available commercially as a hybrid with $S$. cerevisiae and can increase thiol aromatic qualities during fermentation, at lower temperatures, making it ideal for distinctive lagers. S. paradoxus is also available commercially as a hybrid with S. cerevisiae and showed increased fruity and floral esters in wine, and also lends unique characteristics to African umqombothi beer. Hybrids of S. mikatae and S. cerevisiae are not yet commercially available, but they were known to produce increased fruity and perfume aromas even when fermented at low temperatures, marking its potential for remarkable lager beer production. Due to debate on the classification and isolation process of $S$. uvarum in genetic research, there is no commercially available version of this species, but it shows potential as a cryotolerant lager yeast, with more character than S. pastorianus. After recent research, many commercially available $S$. bayanus strains were reclassified as variants of $S$. cerevisiae, but the true hybrids of $S$. bayanus and S. cerevisiae showed increased ethyl esters and spicy notes that could add a complexity to beer production. While much of the research regarding flavor and aroma that is presented in this review might be focused on wine, these species all have potential for novel fermentations and new sensory experiences, if used in beer.

Author Contributions: J.B. conceived the review topic, performed the research, and wrote the manuscript. G.F. supervised the work, offered insight, and assisted with final editing of the manuscript. All authors have read and agreed to the published version of the manuscript.

Funding: This research was funded by the H.A. Jastro Shields Fellowship, Margrit Mondavi Graduate Fellowship, George F. Stewart Memorial Fund, and Michael J. Lewis Endowment.

Acknowledgments: Many thanks to Luxin Wang, Amanda Sinrod, and Jessie Liang of UC Davis Food Science for edits on the first draft of this paper. Thanks to the UC Davis Food Science and Technology Department for promoting research of beer.

Conflicts of Interest: The authors declare no conflict of interest.

\section{References}

1. Legras, J.-L.; Merdinoglu, D.; Cornuet, J.-M.; Karst, F. Bread, beer and wine: Saccharomyces cerevisiae diversity reflects human history. Mol. Ecol. 2007, 16, 2091-2102. [CrossRef]

2. Meussdoerffer, F.G. A comprehensive history of beer brewing. In Handbook of Brewing; Elinger, H.M., Ed.; Wiley-VCH Verlag GmbH \& Co. KGaA: Weinheim, Germany, 2009; pp. 1-42. ISBN 9783527316748.

3. Perruchini, E.; Glatz, C.; Hald, M.M.; Casana, J.; Toney, J.L. Revealing invisible brews: A new approach to the chemical identification of ancient beer. J. Archaeol. Sci. 2018, 100, 176-190. [CrossRef]

4. Liu, L.; Wang, J.; Rosenberg, D.; Zhao, H.; Lengyel, G.; Nadel, D. Fermented beverage and food storage in 13,000 y-old stone mortars at Raqefet Cave, Israel: Investigating Natufian ritual feasting. J. Archaeol. Sci. Rep. 2018, 21, 783-793. [CrossRef]

5. Bamforth, C.W. The Horace Brown Medal. Forever in focus: Researches in malting and brewing sciences. J. Inst. Brew. 2020. [CrossRef] 
6. Balling, K. Die Sacharometrische Bierprobe; Borrosch \& André: Prague, Czechoslavakia, 1842.

7. Joule, J.P. On the calorific effects of magneto-electricity, and on the mechanical value of heat. Lond. Edinb. Dublin Philos. Mag. J. Sci. 1843, 23, 435-443. [CrossRef]

8. Pasteur, L. Études sur le vin: Ses Maladies, Causes qui les Provoquent, Procédés Nouveaux Pour le Conserver et Pour le Vieillir, 2nd ed.; Imprimerie Impériale: Paris, France, 1866.

9. Bamforth, C.W. Scientific Principles of Malting and Brewing; American Society of Brewing Chemists, Ed.; American Society of Brewing Chemists: St. Paul, MN, USA, 2006; pp. 1-246. ISBN 1-881696-08-1.

10. Ziliak, S.T. Retrospectives: Guinnessometrics: The economic foundation of "student's"t. J. Econ. Perspect. 2008, 22, 199-216. [CrossRef]

11. Sörensen, S.P.L. Enzymstudien. II. Mitteilung. Über die Messung und die Bedeutung der Wasserstoffionenkoncentration bei enzymatischen Prozessen. Biochem. Z. 1909, 21, 131-304.

12. Bamforth, C. Beer: Tap Into The Art and Science of Brewing, 3rd ed.; Oxford University Press: Oxford, UK, 2009; p. 239. ISBN 978-0-19-530542-5.

13. Wunderlich, S.; Zürcher, A.; Back, W. Enrichment of xanthohumol in the brewing process. Mol. Nutr. Food Res. 2005, 49, 874-881. [CrossRef] [PubMed]

14. Magalhães, P.J.; Carvalho, D.O.; Cruz, J.M.; Guido, L.F.; Barros, A.A. Fundamentals and health benefits of xanthohumol, a natural product derived from hops and beer. Nat. Prod. Commun. 2009, 4, 591-610. [CrossRef] [PubMed]

15. He, Y.; Dong, J.; Yin, H.; Zhao, Y.; Chen, R.; Wan, X.; Chen, P.; Hou, X.; Liu, J.; Chen, L. Wort composition and its impact on the flavour-active higher alcohol and ester formation of beer-A review. J. Inst. Brew. 2014. [CrossRef]

16. Waterhouse, A.L.; Sacks, G.L.; Jeffery, D.W. Outline of wine production. In Understanding Wine Chemistry; John Wiley \& Sons, Ltd.: Chichester, UK, 2016; pp. 159-171. ISBN 9781118627808.

17. Fleet, G.H. Growth of yeasts during wine fermentations. J. Wine Res. 1990, 1, 211-223. [CrossRef]

18. Tronchoni, J.; Gamero, A.; Arroyo-López, F.N.; Barrio, E.; Querol, A. Differences in the glucose and fructose consumption profiles in diverse Saccharomyces wine species and their hybrids during grape juice fermentation. Int. J. Food Microbiol. 2009, 134, 237-243. [CrossRef] [PubMed]

19. Moritz, E.R.; Morris, G.H. A Text-Book of the Science of Brewing; Spon: London, UK, 1891.

20. Gallone, B.; Steensels, J.; Prahl, T.; Soriaga, L.; Saels, V.; Herrera-Malaver, B.; Merlevede, A.; Roncoroni, M.; Voordeckers, K.; Miraglia, L.; et al. Domestication and Divergence of Saccharomyces cerevisiae Beer Yeasts. Cell 2016, 166, 1397-1410.e16. [CrossRef] [PubMed]

21. Fay, J.C.; Liu, P.; Ong, G.T.; Dunham, M.J.; Cromie, G.A.; Jeffery, E.W.; Ludlow, C.L.; Dudley, A.M. A polyploid admixed origin of beer yeasts derived from European and Asian wine populations. PLoS Biol. 2019, 17, e3000147. [CrossRef] [PubMed]

22. Olesen, K.; Felding, T.; Gjermansen, C.; Hansen, J. The dynamics of the brewing yeast transcriptome during a production-scale lager beer fermentation. Fems Yeast Res. 2002, 2, 563-573. [CrossRef]

23. Denby, C.M.; Li, R.A.; Vu, V.T.; Costello, Z.; Lin, W.; Chan, L.J.G.; Williams, J.; Donaldson, B.; Bamforth, C.W.; Petzold, C.J.; et al. Industrial brewing yeast engineered for the production of primary flavor determinants in hopped beer. Nat. Commun. 2018, 9, 965. [CrossRef]

24. Olaniran, A.O.; Hiralal, L.; Mokoena, M.P.; Pillay, B. Flavour-active volatile compounds in beer: Production, regulation and control. J. Inst. Brew. 2017, 123, 13-23. [CrossRef]

25. Swiegers, J.H.; Bartowsky, E.J.; Henschke, P.A.; Pretorius, I.S. Yeast and bacterial modulation of wine aroma and flavour. Aust. J. Grape Wine Res. 2005, 11, 139-173. [CrossRef]

26. Swiegers, J.H.; Saerens, S.M.G.; Pretorius, I.S. The development of yeast strains as tools for adjusting the flavor of fermented beverages to market specifications. In Biotechnology in Flavor Production; Havkin-Frenkel, D., Belanger, F.C., Eds.; Blackwell Publishing Ltd.: Oxford, UK, 2008; pp. 1-55. ISBN 9781405156493.

27. Berg, J.M.; Tymoczko, J.L.; Stryer, L. Glycolysis is an Energy-Conversion Pathway in Many Organisms. 2002. Available online: https://www.ncbi.nlm.nih.gov/books/NBK22593/ (accessed on 4 May 2020).

28. Aranda, A.; Orozco, H.; Picazo, C.; Matallana, E. Yeast life span and its impact on food fermentations. Fermentation 2019, 5, 37. [CrossRef]

29. Dunham, M.J.; Badrane, H.; Ferea, T.; Adams, J.; Brown, P.O.; Rosenzweig, F.; Botstein, D. Characteristic genome rearrangements in experimental evolution of Saccharomyces cerevisiae. Proc. Natl. Acad. Sci. USA 2002, 99, 16144-16149. [CrossRef] 
30. Gresham, D.; Desai, M.M.; Tucker, C.M.; Jenq, H.T.; Pai, D.A.; Ward, A.; DeSevo, C.G.; Botstein, D.; Dunham, M.J. The repertoire and dynamics of evolutionary adaptations to controlled nutrient-limited environments in yeast. PLoS Genet. 2008, 4, e1000303. [CrossRef] [PubMed]

31. Scannell, D.R.; Zill, O.A.; Rokas, A.; Payen, C.; Dunham, M.J.; Eisen, M.B.; Rine, J.; Johnston, M.; Hittinger, C.T. The Awesome Power of Yeast Evolutionary Genetics: New Genome Sequences and Strain Resources for the Saccharomyces sensu stricto Genus. G3 (Bethesda) 2011, 1, 11-25. [CrossRef] [PubMed]

32. Large, C.R.L.; Hanson, N.A.; Tsouris, A.; Abou Saada, O.; Koonthongkaew, J.; Toyokawa, Y.; Schmidlin, T.; Moreno-Habel, D.A.; McConnellogue, H.; Preiss, R.; et al. Genomic stability and adaptation of beer brewing yeasts during serial repitching in the brewery. BioRxiv 2020. [CrossRef]

33. Mensour, N.A.; Margaritis, A.; Briens, C.L.; Pilkington, H.; Russell, I. Application of immobilized yeast cells in the brewing industry. In Immobilized Cells—Basics and Applications; Progress in Biotechnology; Elsevier: Amsterdam, The Netherlands, 1996; Volume 11, pp. 661-671. ISBN 9780444819840.

34. Marongiu, A.; Zara, G.; Legras, J.-L.; Del Caro, A.; Mascia, I.; Fadda, C.; Budroni, M. Novel starters for old processes: Use of Saccharomyces cerevisiae strains isolated from artisanal sourdough for craft beer production at a brewery scale. J. Ind. Microbiol. Biotechnol. 2015, 42, 85-92. [CrossRef] [PubMed]

35. Canonico, L.; Comitini, F.; Ciani, M. Metschnikowia pulcherrima Selected Strain for Ethanol Reduction in Wine: Influence of Cell Immobilization and Aeration Condition. Foods 2019, 8, 378. [CrossRef]

36. Canonico, L.; Agarbati, A.; Comitini, F.; Ciani, M. Torulaspora delbrueckii in the brewing process: A new approach to enhance bioflavour and to reduce ethanol content. Food Microbiol. 2016, 56, 45-51. [CrossRef]

37. Varela, C. The impact of non-Saccharomyces yeasts in the production of alcoholic beverages. Appl. Microbiol. Biotechnol. 2016, 100, 9861-9874. [CrossRef]

38. Michel, M.; Meier-Dörnberg, T.; Jacob, F.; Methner, F.-J.; Wagner, R.S.; Hutzler, M. Review: Pure nonSaccharomyces starter cultures for beer fermentation with a focus on secondary metabolites and practical applications. J. Inst. Brew. 2016, 122, 569-587. [CrossRef]

39. Basso, R.F.; Alcarde, A.R.; Portugal, C.B. Could non-Saccharomyces yeasts contribute on innovative brewing fermentations? Food Res. Int. 2016, 86, 112-120. [CrossRef]

40. Alonso-Del-Real, J.; Lairón-Peris, M.; Barrio, E.; Querol, A. Effect of Temperature on the Prevalence of Saccharomyces Non cerevisiae Species against a S. cerevisiae Wine Strain in Wine Fermentation: Competition, Physiological Fitness, and Influence in Final Wine Composition. Front. Microbiol. 2017, 8, 150. [CrossRef]

41. Pérez-Torrado, R.; Barrio, E.; Querol, A. Alternative yeasts for winemaking: Saccharomyces non-cerevisiae and its hybrids. Crit. Rev. Food Sci. Nutr. 2018, 58, 1780-1790. [CrossRef] [PubMed]

42. Kodama, Y.; Kielland-Brandt, M.C.; Hansen, J. Lager brewing yeast. In Comparative Genomics; Sunnerhagen, P., Piskur, J., Eds.; Springer: Berlin/Heidelberg, Germany, 2006; pp. 145-164. ISBN 978-3-540-31480-6.

43. Rainieri, S.; Kodama, Y.; Kaneko, Y.; Mikata, K.; Nakao, Y.; Ashikari, T. Pure and mixed genetic lines of Saccharomyces bayanus and Saccharomyces pastorianus and their contribution to the lager brewing strain genome. Appl. Environ. Microbiol. 2006, 72, 3968-3974. [CrossRef]

44. Gibson, B.; Liti, G. Saccharomyces pastorianus: Genomic insights inspiring innovation for industry. Yeast 2015, 32, 17-27. [CrossRef] [PubMed]

45. White, C.; Zainasheff, J. Yeast: The Practical Guide To Beer Fermentation; Brewers Publications: Boulder, CO, USA, 2010; p. 300. ISBN 978-0937381960.

46. Mortimer, R.K. Evolution and variation of the yeast (Saccharomyces) genome. Genome Res. 2000, 10, 403-409. [CrossRef] [PubMed]

47. Naumov, G.I.; James, S.A.; Naumova, E.S.; Louis, E.J.; Roberts, I.N. Three new species in the Saccharomyces sensu stricto complex: Saccharomyces cariocanus, Saccharomyces kudriavzevii and Saccharomyces mikatae. Int. J. Syst. Evol. Microbiol. 2000, 50, 1931-1942. [CrossRef]

48. Borneman, A.R.; Pretorius, I.S. Genomic insights into the Saccharomyces sensu stricto complex. Genetics 2015, 199, 281-291. [CrossRef]

49. Naumov, G. Genetic identification of biological species in the Saccharomyces sensu stricto complex. J. Ind. Microbiol. Biotechnol. 1996, 17, 295-302. [CrossRef]

50. Bing, J.; Han, P.-J.; Liu, W.-Q.; Wang, Q.-M.; Bai, F.-Y. Evidence for a Far East Asian origin of lager beer yeast. Curr. Biol. 2014, 24, R380-1. [CrossRef] 
51. Fay, J.C. Tapping into yeast diversity. Mol. Ecol. 2012, 21, 5387-5389. [CrossRef]

52. Sampaio, J.P.; Gonçalves, P. Natural populations of Saccharomyces kudriavzevii in Portugal are associated with oak bark and are sympatric with S. cerevisiae and S. paradoxus. Appl. Environ. Microbiol. 2008, 74, 2144-2152. [CrossRef]

53. Erny, C.; Raoult, P.; Alais, A.; Butterlin, G.; Delobel, P.; Matei-Radoi, F.; Casaregola, S.; Legras, J.L. Ecological success of a group of Saccharomyces cerevisiae/Saccharomyces kudriavzevii hybrids in the northern european wine-making environment. Appl. Environ. Microbiol. 2012, 78, 3256-3265. [CrossRef] [PubMed]

54. Peris, D.; Pérez-Torrado, R.; Hittinger, C.T.; Barrio, E.; Querol, A. On the origins and industrial applications of Saccharomyces cerevisiae $\times$ Saccharomyces kudriavzevii hybrids. Yeast 2018, 35, 51-69. [CrossRef]

55. Kellis, M.; Patterson, N.; Endrizzi, M.; Birren, B.; Lander, E.S. Sequencing and comparison of yeast species to identify genes and regulatory elements. Nature 2003, 423, 241-254. [CrossRef] [PubMed]

56. González, S.S.; Barrio, E.; Querol, A. Molecular characterization of new natural hybrids of Saccharomyces cerevisiae and S. kudriavzevii in brewing. Appl. Environ. Microbiol. 2008, 74, 2314-2320. [CrossRef] [PubMed]

57. Scholtes, C.; Nizet, S.; Collin, S. Guaiacol and 4-methylphenol as specific markers of torrefied malts. Fate of volatile phenols in special beers through aging. J. Agric. Food Chem. 2014, 62, 9522-9528. [CrossRef] [PubMed]

58. Henriques, D.; Alonso-Del-Real, J.; Querol, A.; Balsa-Canto, E. Saccharomyces cerevisiae and S. kudriavzevii Synthetic Wine Fermentation Performance Dissected by Predictive Modeling. Front. Microbiol. 2018, 9, 88. [CrossRef] [PubMed]

59. Gallone, B.; Steensels, J.; Mertens, S.; Dzialo, M.C.; Gordon, J.L.; Wauters, R.; Theßeling, F.A.; Bellinazzo, F.; Saels, V.; Herrera-Malaver, B.; et al. Interspecific hybridization facilitates niche adaptation in beer yeast. Nat. Ecol. Evol. 2019, 3, 1562-1575. [CrossRef]

60. Groth, C.; Hansen, J.; Piskur, J. A natural chimeric yeast containing genetic material from three species. Int. J. Syst. Bacteriol. 1999, 49, 1933-1938. [CrossRef]

61. Masneuf, I.; Hansen, J.; Groth, C.; Piskur, J.; Dubourdieu, D. New hybrids between Saccharomyces sensu stricto yeast species found among wine and cider production strains. Appl. Environ. Microbiol. 1998, 64, 3887-3892. [CrossRef]

62. Belloch, C.; Orlic, S.; Barrio, E.; Querol, A. Fermentative stress adaptation of hybrids within the Saccharomyces sensu stricto complex. Int. J. Food Microbiol. 2008, 122, 188-195. [CrossRef]

63. Salvadó, Z.; Arroyo-López, F.N.; Guillamón, J.M.; Salazar, G.; Querol, A.; Barrio, E. Temperature adaptation markedly determines evolution within the genus Saccharomyces. Appl. Environ. Microbiol. 2011, 77, 2292-2302. [CrossRef]

64. VIN 7. Available online: http://www.oenobrands.com/en/our-brands/anchor/new-world-wine-yeasts/ product-data-sheets/vin-7 (accessed on 27 April 2020).

65. Jolly, N.P.; Augustyn, O.P.H.; Pretorius, I.S. The Role and Use of Non-Saccharomyces Yeasts in Wine Production. SAJEV 2017, 27. [CrossRef]

66. Martini, A.V.; Martini, A. A.V.; Martini, A. A proposal for correct nomenclature of the domesticated species of the genus saccharomyces. In Biotechnology Applications in Beverage Production; Cantarelli, C., Lanzarini, G., Eds.; Springer: Dordrecht, The Netherlands, 1989; pp. 1-16. ISBN 978-94-009-1113-0.

67. Sniegowski, P.D.; Dombrowski, P.G.; Fingerman, E. Saccharomyces cerevisiae and Saccharomyces paradoxus coexist in a natural woodland site in North America and display different levels of reproductive isolation from European conspecifics. Fems Yeast Res. 2002, 1, 299-306. [CrossRef] [PubMed]

68. Hyma, K.E.; Fay, J.C. Mixing of vineyard and oak-tree ecotypes of Saccharomyces cerevisiae in North American vineyards. Mol. Ecol. 2013, 22, 2917-2930. [CrossRef]

69. Charron, G.; Leducq, J.-B.; Bertin, C.; Dubé, A.K.; Landry, C.R. Exploring the northern limit of the distribution of Saccharomyces cerevisiae and Saccharomyces paradoxus in North America. Fems Yeast Res. 2014, 14, 281-288. [CrossRef] [PubMed]

70. Liti, G.; Carter, D.M.; Moses, A.M.; Warringer, J.; Parts, L.; James, S.A.; Davey, R.P.; Roberts, I.N.; Burt, A.; Koufopanou, V.; et al. Population genomics of domestic and wild yeasts. Nature 2009, 458, 337-341. [CrossRef] [PubMed] 
71. Roop, J.I.; Brem, R.B. Rare variants in hypermutable genes underlie common morphology and growth traits in wild Saccharomyces paradoxus. Genetics 2013, 195, 513-525. [CrossRef]

72. Redzepović, S.; Orlić, S.; Sikora, S.; Majdak, A.; Pretorius, I.S. Identification and characterization of Saccharomyces cerevisiae and Saccharomyces paradoxus strains isolated from Croatian vineyards. Lett. Appl. Microbiol. 2002, 35, 305-310. [CrossRef]

73. Orlic, S.; Redzepovic, S.; Jeromel, A.; Herjavec, S.; Iacumin, L. Influence of indigenous Saccharomyces paradoxus strains on Chardonnay wine fermentation aroma. Int. J. Food Sci. Technol. 2007, 42, 95-101. [CrossRef]

74. Majdak, A.; Herjavec, S.; Orlic, S.; Redzepovic, S.; Mirosevic, N. Comparison of Wine Aroma Compounds Produced by Saccharomyces paradoxus and Saccharomyces cerevisiae Strains. Food Technol. Biotechnol. 2002, 40, 103-109.

75. Naumova, E.; Korshunova, I.; Jespersen, L.; Naumov, G. Molecular genetic identification of sensu stricto strains from African sorghum beer. Fems Yeast Res. 2003, 3, 177-184. [CrossRef]

76. Sweeney, J.; Kuehne, H.; Sniegowski, P. Sympatric natural and populations have different thermal growth profiles. Fems Yeast Res. 2004, 4, 521-525. [CrossRef]

77. Gonçalves, P.; Valério, E.; Correia, C.; de Almeida, J.M.G.C.F.; Sampaio, J.P. Evidence for divergent evolution of growth temperature preference in sympatric Saccharomyces species. PLoS ONE 2011, 6, e20739. [CrossRef]

78. Rollero, S.; Bloem, A.; Ortiz-Julien, A.; Camarasa, C.; Divol, B. Fermentation performances and aroma production of non-conventional wine yeasts are influenced by nitrogen preferences. Fems Yeast Res. 2018, 18. [CrossRef] [PubMed]

79. Dunn, B.; Richter, C.; Kvitek, D.J.; Pugh, T.; Sherlock, G. Analysis of the Saccharomyces cerevisiae pan-genome reveals a pool of copy number variants distributed in diverse yeast strains from differing industrial environments. Genome Res. 2012, 22, 908-924. [CrossRef]

80. Bellon, J.R.; Schmid, F.; Capone, D.L.; Dunn, B.L.; Chambers, P.J. Introducing a new breed of wine yeast: Interspecific hybridisation between a commercial Saccharomyces cerevisiae wine yeast and Saccharomyces mikatae. PLoS ONE 2013, 8, e62053. [CrossRef] [PubMed]

81. Bellon, J.; Schmidt, S.; Solomon, M. Case study: Development of Saccharomyces cerevisiae $\times$ Saccharomyces mikatae wine yeast hybrids and their potential to deliver alternative wine styles. AWRI Tech. Rev. 2019, 241, 6-11.

82. Pulvirenti, A.; Nguyen, H.; Caggia, C.; Giudici, P.; Rainieri, S.; Zambonelli, C. Saccharomyces uvarum, a proper species within Saccharomyces sensu stricto. FEMS Microbiol. Lett. 2000, 192, 191-196. [CrossRef]

83. Nguyen, H.-V.; Gaillardin, C. Evolutionary relationships between the former species Saccharomyces uvarum and the hybrids Saccharomyces bayanus and Saccharomyces pastorianus; reinstatement of Saccharomyces uvarum (Beijerinck) as a distinct species. FEMS Yeast Res. 2005, 5, 471-483. [CrossRef]

84. Rainieri, S.; Zambonelli, C.; Hallsworth, J.E.; Pulvirenti, A.; Giudici, P. Saccharomyces uvarum, a distinct group within Saccharomyces sensu stricto. FEMS Microbiol. Lett. 1999, 177, 177-185. [CrossRef]

85. Naumova, E.S.; Naumov, G.I.; Masneuf-Pomarède, I.; Aigle, M.; Dubourdieu, D. Molecular genetic study of introgression between Saccharomyces bayanus and S. cerevisiae. Yeast 2005, 22, 1099-1115. [CrossRef] [PubMed]

86. Demuyter, C.; Lollier, M.; Legras, J.L.; Le Jeune, C. Predominance of Saccharomyces uvarum during spontaneous alcoholic fermentation, for three consecutive years, in an Alsatian winery. J. Appl. Microbiol. 2004, 97, 1140-1148. [CrossRef] [PubMed]

87. Tosi, E.; Azzolini, M.; Guzzo, F.; Zapparoli, G. Evidence of different fermentation behaviours of two indigenous strains of Saccharomyces cerevisiae and Saccharomyces uvarum isolated from Amarone wine. J. Appl. Microbiol. 2009, 107, 210-218. [CrossRef] [PubMed]

88. Rodríguez, M.E.; Pérez-Través, L.; Sangorrín, M.P.; Barrio, E.; Querol, A.; Lopes, C.A. Saccharomyces uvarum is responsible for the traditional fermentation of apple chicha in Patagonia. FEMS Yeast Res. 2017, 17. [CrossRef] [PubMed]

89. Rodríguez, M.E.; Pérez-Través, L.; Sangorrín, M.P.; Barrio, E.; Lopes, C.A. Saccharomyces eubayanus and Saccharomyces uvarum associated with the fermentation of Araucaria araucana seeds in Patagonia. FEMS Yeast Res. 2014, 14, 948-965. [CrossRef] [PubMed] 
90. Beijerinck, M.W. Über Regeneration der Sporenbildung bei Alkoholhefen, wo diese Function im Verschwinden begriffen ist. Cent. Bakteriol. Parasitenkd. 1898, 4, 721-730.

91. Krogerus, K.; Preiss, R.; Gibson, B. A Unique Saccharomyces cerevisiae $\times$ Saccharomyces uvarum Hybrid Isolated from Norwegian Farmhouse Beer: Characterization and Reconstruction. Front. Microbiol. 2018, 9, 2253. [CrossRef]

92. Nguyen, H.-V.; Boekhout, T. Characterization of Saccharomyces uvarum (Beijerinck, 1898) and related hybrids: Assessment of molecular markers that predict the parent and hybrid genomes and a proposal to name yeast hybrids. Fems Yeast Res. 2017, 17. [CrossRef]

93. Krogerus, K.; Gibson, B. A re-evaluation of diastatic Saccharomyces cerevisiae strains and their role in brewing. Appl. Microbiol. Biotechnol. 2020, 104, 3745-3756. [CrossRef]

94. Smukowski Heil, C.S.; Large, C.R.L.; Patterson, K.; Hickey, A.S.-M.; Yeh, C.-L.C.; Dunham, M.J. Temperature preference can bias parental genome retention during hybrid evolution. PLoS Genet. 2019, 15, e1008383. [CrossRef]

95. Morgan, S.C.; Haggerty, J.J.; Jiranek, V.; Durall, D.M. Competition between Saccharomyces cerevisiae and Saccharomyces uvarum in Controlled Chardonnay Wine Fermentations. Am. J. Enol. Vitic. 2020. [CrossRef]

96. Feuillat, M. Use of Yeasts in Burgandy and In Other Regions: Fermentation and Ading on Lees. In Yeast's Contribution to the Sensory Profile of Wine: Maintaining Typicity and Biodiversity in the Context of Globalization; Lallemand, S.A.S., Ed.; Entretiens Scientifiques: Wiesbaden, Germany, 2005; Volume XVII, pp. 27-32.

97. Le Jeune, C.; Lollier, M.; Demuyter, C.; Erny, C.; Legras, J.-L.; Aigle, M.; Masneuf-Pomarède, I. Characterization of natural hybrids of Saccharomyces cerevisiae and Saccharomyces bayanus var. uvarum. FEMS Yeast Res. 2007, 7, 540-549. [CrossRef] [PubMed]

98. Available Microbial Strains-The Australian Wine Research Institute. Available online: https://www.awri.com. au/research_and_development/wine-microorganism/winemaking-yeast-and-bacterial-strains/ (accessed on 3 May 2020).

99. Caudy, A.A.; Guan, Y.; Jia, Y.; Hansen, C.; DeSevo, C.; Hayes, A.P.; Agee, J.; Alvarez-Dominguez, J.R.; Arellano, H.; Barrett, D.; et al. A new system for comparative functional genomics of Saccharomyces yeasts. Genetics 2013, 195, 275-287. [CrossRef]

100. Vaughan Martini, A.; Kurtzman, C.P. Deoxyribonucleic Acid Relatedness among Species of the Genus Saccharomyces Sensu Stricto. Int. J. Syst. Bacteriol. 1985, 35, 508-511. [CrossRef]

101. Nguyen, H.-V.; Legras, J.-L.; Neuvéglise, C.; Gaillardin, C. Deciphering the hybridisation history leading to the Lager lineage based on the mosaic genomes of Saccharomyces bayanus strains NBRC1948 and CBS380. PLOS ONE 2011, 6, e25821. [CrossRef] [PubMed]

102. Libkind, D.; Hittinger, C.T.; Valério, E.; Gonçalves, C.; Dover, J.; Johnston, M.; Gonçalves, P.; Sampaio, J.P. Microbe domestication and the identification of the wild genetic stock of lager-brewing yeast. Proc. Natl. Acad. Sci. USA 2011, 108, 14539-14544. [CrossRef] [PubMed]

103. De Almeida, P.M.C. Microbe Domestication and the Identification of the Wild Genetic Stock of Wine Yeasts. Proc. Natl. Acad. Sci. USA 2016. Available online: http://hdl.handle.net/10362/19871 (accessed on 24 November 2020).

104. González, S.S.; Barrio, E.; Gafner, J.; Querol, A. Natural hybrids from Saccharomyces cerevisiae, Saccharomyces bayanus and Saccharomyces kudriavzevii in wine fermentations. FEMS Yeast Res. 2006, 6, 1221-1234. [CrossRef]

105. Wendland, J. Lager yeast comes of age. Eukaryot. Cell 2014, 13, 1256-1265. [CrossRef]

106. Sicard, D.; Legras, J.-L. Bread, beer and wine: Yeast domestication in the Saccharomyces sensu stricto complex. C. R. Biol. 2011, 334, 229-236. [CrossRef]

107. Ugliano, M.; Fedrizzi, B.; Siebert, T.; Travis, B.; Magno, F.; Versini, G.; Henschke, P.A. Effect of nitrogen supplementation and Saccharomyces species on hydrogen sulfide and other volatile sulfur compounds in shiraz fermentation and wine. J. Agric. Food Chem. 2009, 57, 4948-4955. [CrossRef] [PubMed]

108. Fernández-Espinar, M. Study of the authenticity of commercial wine yeast strains by molecular techniques. Int. J. Food Microbiol. 2001, 70, 1-10. [CrossRef] 
109. Hoff, J.W. Molecular Typing of Wine Yeasts: Evaluation of Typing Techniques and Establishment of a Database. 2012. Available online: https://citeseerx.ist.psu.edu/viewdoc/download?doi=10.1.1.933.7961\& rep $=$ rep1\&type $=$ pdf (accessed on 1 May 2020).

110. Nakao, Y.; Kanamori, T.; Itoh, T.; Kodama, Y.; Rainieri, S.; Nakamura, N.; Shimonaga, T.; Hattori, M.; Ashikari, T. Genome sequence of the lager brewing yeast, an interspecies hybrid. DNA Res. 2009, 16, 115-129. [CrossRef] [PubMed]

111. Cordente, A.G.; Curtin, C.D.; Varela, C.; Pretorius, I.S. Flavour-active wine yeasts. Appl. Microbiol. Biotechnol. 2012, 96, 601-618. [CrossRef]

112. Hisamoto, M.; Furuya, T.; Yanagida, A.; Okuda, T.; Sato, M. Phenolic off Flavor Characterization of Commercially Available Wine Yeasts and Selection of the Yeast for Koshu Winemaking. J. ASEV Jpn. 2010, 21, 112-117.

113. Ward, H.M. V. the ginger-beer plant, and the organisms composing it: A contribution to the study of fermentation-yeasts and bacteria. Philos. Trans. R. Soc. Lond. B 1892, 183, 125-197. [CrossRef]

114. Pidoux, M. The microbial flora of sugary kefir grain (the gingerbeer plant): Biosynthesis of the grain fromLactobacillus hilgardii producing a polysaccharide gel. World J. Microbiol. Biotechnol. 1989, 5, 223-238. [CrossRef]

115. Naumov, G.I.; Naumova, E.S.; Masneuf-Pomarède, I. Genetic identification of new biological species Saccharomyces arboricolus Wang et Bai. Antonie Van Leeuwenhoek 2010, 98, 1-7. [CrossRef]

116. Wang, S.-A.; Bai, F.-Y. Saccharomyces arboricolus sp. nov., a yeast species from tree bark. Int. J. Syst. Evol. Microbiol. 2008, 58, 510-514. [CrossRef]

117. Winans, M.J.; Yamamoto, Y.; Fujimaru, Y.; Kusaba, Y.; Gallagher, J.E.G.; Kitagaki, H. Saccharomyces arboricola and Its Hybrids' Propensity for Sake Production: Interspecific Hybrids Reveal Increased Fermentation Abilities and a Mosaic Metabolic Profile. Fermentation 2020, 6, 14. [CrossRef]

118. Naseeb, S.; James, S.A.; Alsammar, H.; Michaels, C.J.; Gini, B.; Nueno-Palop, C.; Bond, C.J.; McGhie, H.; Roberts, I.N.; Delneri, D. Suppl. Saccharomyces jurei sp. nov., isolation and genetic identification of a novel yeast species from Quercus robur. Int. J. Syst. Evol. Microbiol. 2017, 67, 2046-2052. [CrossRef] [PubMed]

119. Liti, G.; Barton, D.B.H.; Louis, E.J. Sequence diversity, reproductive isolation and species concepts in Saccharomyces. Genetics 2006, 174, 839-850. [CrossRef] [PubMed]

120. Barbosa, R.; Almeida, P.; Safar, S.V.B.; Santos, R.O.; Morais, P.B.; Nielly-Thibault, L.; Leducq, J.-B.; Landry, C.R.; Gonçalves, P.; Rosa, C.A.; et al. Evidence of Natural Hybridization in Brazilian Wild Lineages of Saccharomyces cerevisiae. Genome Biol. Evol. 2016, 8, 317-329. [CrossRef] [PubMed]

121. de Paula, B.P.; Chávez, D.W.H.; Lemos Junior, W.J.F.; Guerra, A.F.; Corrêa, M.F.D.; Pereira, K.S.; Coelho, M.A.Z. Growth Parameters and Survivability of Saccharomyces boulardii for Probiotic Alcoholic Beverages Development. Front. Microbiol. 2019, 10, 2092. [CrossRef] [PubMed]

122. Capece, A.; Romaniello, R.; Pietrafesa, A.; Siesto, G.; Pietrafesa, R.; Zambuto, M.; Romano, P. Use of Saccharomyces cerevisiae var. boulardii in co-fermentations with $\mathrm{S}$. cerevisiae for the production of craft beers with potential healthy value-added. Int. J. Food Microbiol. 2018, 284, 22-30. [CrossRef]

123. Mulero-Cerezo, J.; Briz-Redón, Á.; Serrano-Aroca, Á. Saccharomyces cerevisiae var. boulardii: Valuable probiotic starter for craft beer production. Appl. Sci. 2019, 9, 3250. [CrossRef]

124. Van der Aa Kühle, A.; Jespersen, L. The taxonomic position of Saccharomyces boulardii as evaluated by sequence analysis of the D1/D2 domain of 26S rDNA, the ITS1-5.8S rDNA-ITS2 region and the mitochondrial cytochrome-c oxidase II gene. Syst. Appl. Microbiol. 2003, 26, 564-571. [CrossRef]

125. Ramírez-Cota, G.Y.; López-Villegas, E.O.; Jiménez-Aparicio, A.R.; Hernández-Sánchez, H. Modeling the Ethanol Tolerance of the Probiotic Yeast Saccharomyces cerevisiae var. boulardii CNCM I-745 for its Possible Use in a Functional Beer. Probiotics Antimicrob. Proteins 2020. [CrossRef]

126. Sampaolesi, S.; Gamba, R.R.; De Antoni, G.L.; León Peláez, Á.M. Potentiality of yeasts obtained as beer fermentation residue to be used as probiotics. LWT 2019, 113, 108251. [CrossRef]

127. Sakai, K.; Fukui, S.; Yabuuchi, S.; Aoyagi, S.; Tsumura, Y. Expression of the saccharomyces diastaticus sta1 gene in brewing yeasts. ASBCJ 1989, 47, 87-91. [CrossRef] 
128. Meier-Dörnberg, T.; Kory, O.I.; Jacob, F.; Michel, M.; Hutzler, M. Saccharomyces cerevisiae variety diastaticus friend or foe?-spoilage potential and brewing ability of different Saccharomyces cerevisiae variety diastaticus yeast isolates by genetic, phenotypic and physiological characterization. FEMS Yeast Res. 2018, 18. [CrossRef] [PubMed]

129. Yamauchi, H.; Yamamoto, H.; Shibano, Y.; Amaya, N.; Saeki, T. Rapid methods for detecting Saccharomyces diastaticus, a beer spoilage yeast, using the polymerase chain reaction. ASBCJ 1998, 56, 58-63. [CrossRef]

Publisher's Note: MDPI stays neutral with regard to jurisdictional claims in published maps and institutional affiliations.

(C) 2020 by the authors. Licensee MDPI, Basel, Switzerland. This article is an open access article distributed under the terms and conditions of the Creative Commons Attribution (CC BY) license (http://creativecommons.org/licenses/by/4.0/). 